\title{
Supratentorial Cysts: Prenatal Diagnosis and Outcome
}

\author{
${ }^{1}$ Mariangela Cialdella, ${ }^{2}$ Pasquale Capuano, ${ }^{3}$ Vincenzo D'Addario
}

\begin{abstract}
Fetal intracranial supratentorial cysts may develop in the cerebral parenchyma or in the ventricles. They can have different sizes, positions, and relationships with other intracranial structures. Three different groups of cysts may be described: Intraparenchymal, intraventricular, and extra-axial. This review describes the prenatal sonographic findings of the fetal supratentorial cysts, their association with central nervous system (CNS) and extra-CNS anomalies, their clinical significance, and their outcome.
\end{abstract}

Keywords: Brain cysts, Extra-axial cysts, Intraventricular cyst. How to cite this article: Cialdella M, Capuano P, D'Addario V. Supratentorial Cysts: Prenatal Diagnosis and Outcome. Donald School J Ultrasound Obstet Gynecol 2017;11(4):302-307.

Source of support: Nil

Conflict of interest: None

\section{INTRODUCTION}

Fetal intracranial cysts are cancel lesions that arise in cerebral parenchyma or ventricles. Intracranial cysts may be classified into three groups:

- Intraparenchymal cysts: periventricular pseudocysts (PVPCs), porencephalic cysts

- Intraventricular cysts: choroid plexus cysts

- Extra-axial cysts: arachnoid cyst and cavum veli interpositi (CVI) cysts

When intracranial cyst is found, it is necessary to evaluate the position, the dimension, the relationship with other intracranial structures, the presence of a solid tissue, and their vascularization with color Doppler. ${ }^{1}$

\section{INTRAPARENCHYMAL CYST}

\section{Porencephalic Cyst}

They arise as a result of an ischemic event that leads to a focal necrosis of cerebral tissue..$^{2-4}$ In keeping with the etymology, porencephaly should refer to a hole (porus) in the brain that communicates with or opens into either the ventricular system or subarachnoid spaces. ${ }^{5}$ Pathogenesis of the onset of porencephalic cyst seems to be related to a

\footnotetext{
${ }^{1}$ Resident, ${ }^{2}$ Consultant, ${ }^{3}$ Professor

${ }^{1,3}$ Department of Obstetrics and Gynecology, University of Bari Bari, Italy

${ }^{2}$ Obstetrics and Gynecology Unit, Barletta Hospital, Italy

Corresponding Author: Mariangela Cialdella, Resident Department of Obstetrics and Gynecology, University of Bari Bari, Italy, e-mail: mariangela.cialdella@libero.it
}

vascular occlusion that leads to the infarction responsible for reabsorption of the cerebral tissue located downstream of the occluded vessel and consequent replacement by a fluid collection. In case of multiple cysts, the term used is multicystic encephalomalacia.

On ultrasound, the cyst is often unilateral with a possible irregular surface not covered by a cortical plane; frequently, it communicates with the ipsilateral ventricle (Fig. 1) and/or the subarachnoid space. Rarely, it can develop into the parenchyma, causing the destruction of brain tissue without any mass effect. Sometimes, if the lesions are into the hemisphere closed to the probe, prenatal diagnosis may be missed. ${ }^{6}$ Ventriculomegaly may be associated.

The differential diagnosis is with unilateral schizencephaly; in this case, usually, the lesions have a smooth brain surface, while porencephalic cysts are roundish with a jagged surface and possible clots or brain tissue residual inside. The differential diagnosis is also with arachnoid cysts that are asymmetric with a smooth surface, not communicating with the lateral ventricle. Arachnoid cyst can result in mass effect due to compression of the surrounding tissue.

The prognosis is generally poor, and depends upon the position of lesions and from how much brain tissue has been destroyed that can lead to seizures, developmental delay, hemiparesis, and mental retardation., ${ }^{7,8}$

\section{Periventricular Pseudocysts}

They are cystic cavities that lack the ependymal cell lining found in true cysts. ${ }^{9}$ They are found in 0.5 to $5 \%$

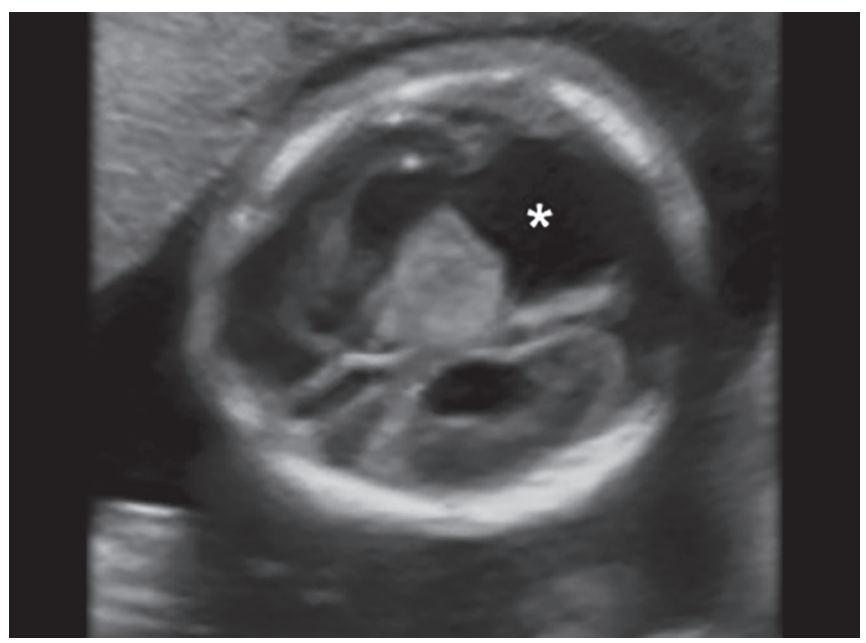

Fig. 1: Porencephalic cyst $(*)$ communicating with an enlarged ventricle 
of healthy term neonates by using transfontanellar sonography in the first days of life. ${ }^{10,11}$ They may be unilateral or bilateral, unilocular or multilocular, mostly located at the thalamus and the caudate core. The PVPC occurs in the germinal matrix during the time of its exponential development in the beginning of the second trimester and during its rapid lysis toward its end. Rademaker et $\mathrm{al}^{12}$ suggested that they should be referred as "germinolytic cysts," also named subependymal cysts due to lysis of the germinal matrix, which is particularly sensitive to this process due to the high mitotic activity. They have been described in association with congenital infections [Rubella virus, cytomegalovirus (CMV), Zika virus], ${ }^{13-16}$ metabolic disorders, ${ }^{17}$ maternal cocaine abuse, ${ }^{18,19}$ and chromosomal aberration, particularly with microdeletion (4p-). ${ }^{20}$ Some cases associated with mitochondrial disorders have also been reported. ${ }^{21}$ In most cases, however, PVPCs have been reported as isolated findings with no clinical significance. When PVPC is found, it is necessary to perform CMV test, Rubella test, and Zika test and search for other cerebral and extracerebral anomalies. In the literature, several studies suggested an association between the morphologic features of PVPC and the etiology.

Epelman et $\mathrm{al}^{22}$ divided PVPCs into connatal cysts, also known as frontal horn cysts, and subependymal pseudocysts (SEPCs). Connatal cysts are located at the external angle, anterior to the foramina of Monro. The SEPCs are located posterior to the foramina of Monro (Fig. 2). Esteban et $\mathrm{al}^{23}$ conducted a retrospective study and identified the ultrasound features of the SEPC that could suggest a hidden hallmark of fetal abnormalities with consequent indication for further diagnostic insights (magnetic resonance imaging, genetic tests). In these selected cases, the SEPCs were situated adjacent to the temporal horn or behind of the caudal thalamic nucleus;

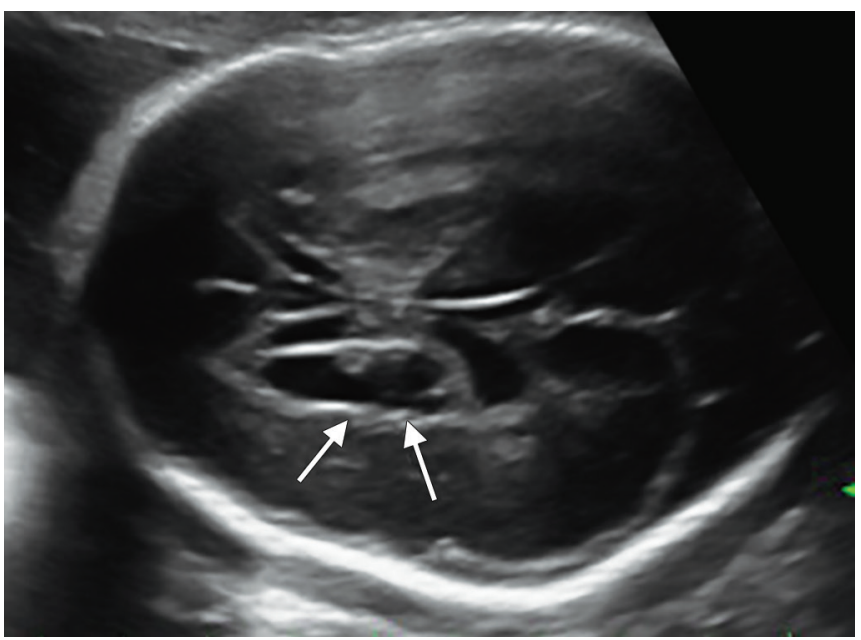

Fig. 2: Multiple SEPCs (arrows) they had an "atypical" morphology or irregular surface with the dimension that was more than $9 \mathrm{~mm}$ along their major axis. These sonographic features correlated with a bad outcome and often with the presence of associated anomalies.

The differential diagnosis is with periventricular leukomalacia. Rademaker et $\mathrm{al}^{12}$ and Malinger et $\mathrm{al}^{24}$ differentiated PVPCs, which are found below the external angle of the lateral ventricles, from periventricular leukomalacia, which is located above it and carries a different prognosis (Fig. 3).

\section{INTRAVENTRICULAR CYSTS}

\section{Choroid Plexus Cysts}

The choroid plexus is a plexus of cells that produce the cerebrospinal fluid (CSF) located throughout the ventricular system of the brain, but particularly developed in the lateral ventricles. The choroid plexus consists of modified ependymal cells. Choroid plexus cysts (CPCs) are of neuroectodermal origin and are angiomatous enlargements of capillaries of the choroid plexus; they may be found after the 17th week of pregnancy and, in most cases, regress after the 26th week or in early infancy. Their incidence varies from 0.18 to $3.6 \%$. On ultrasound, CPCs are defined as sonolucent, unilocular, or septated cystic spaces in the choroid plexus larger than $3 \mathrm{~mm}$ in diameter. ${ }^{25}$ They have been reported as a sonographic marker of trisomy $18 .^{26-28}$ However, trisomy 18 is often associated with other anomalies that involve CNS malformations, heart defects, and limbs anomalies. When CPCs are isolated, this risk is extremely low. ${ }^{27-30}$ The CPCs, in the majority of cases, disappear with advancing gestation; however, symptomatic cysts of the choroid plexus in the lateral ventricle in children and adults have been described. ${ }^{30-33}$

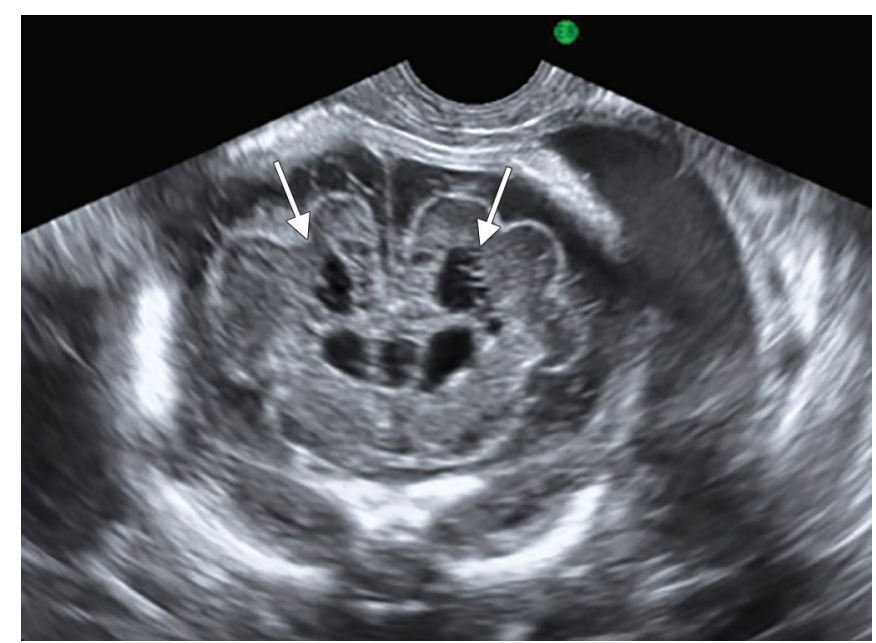

Fig. 3: Periventricular leukomalacia: The cysts (arrows) are located above the lateral ventricles 


\section{EXTRA-AXIAL SUPRATENTORIAL CYSTS}

\section{Arachnoid Cysts}

They are cystic collections of fluid formed by the duplication or splitting of the arachnoid membrane and contain CSF-like fluid. ${ }^{34,35}$ The walls of these cysts contain a thick layer of collagen and hyperplastic arachnoid cells, and they are devoid of the characteristic trabecular processes of the arachnoid. The cysts can be primary without any communication with the subarachnoid space or ventricular system; or it can be secondary to trauma, infection, or hemorrhage, with connections to the subarachnoid space. The most highly valued pathogenetic theory on the arachnoid primary cyst is based on a discontinuity in the neural mesencephalic crest that occurred during formation of the meninges, with consequent discontinuity of the primordial membrane filled with the CSF. Secondary arachnoid cysts are the result of discontinuity due to intrauterine hemorrhage, infections, or trauma. ${ }^{36-39}$ Most arachnoid cysts are isolated lesions; the rare association with other malformations, such as agenesis of the corpus callosum, can affect the prognosis. ${ }^{40}$ They are frequently localized in the diaphragma sellae, in the anterior or medium fossa; less frequently, they are located in the posterior fossa. ${ }^{41}$ On ultrasound, the cysts are anechoic and roundish with well-defined thin walls; they can be uni- or multilocular, single or multiple, with no communication with ventricular cavity (Fig. 4). If the cyst obstructs the foramina of Monro or displaces the aqueduct, the mass effect of the cyst can alter the CSF dynamics, leading to ventriculomegaly. ${ }^{42}$ Most often, arachnoid cysts are supratentorial, with $60 \%$ located in the middle fossa, $10 \%$ in the quadrigeminal cistern, $10 \%$ in the suprasellar cistern (Fig. 5), 10\% over the cerebral convexity, and $10 \%$ in the posterior fossa. ${ }^{43}$

Generally, the cyst is isolated; however, associated intracranial and extracranial anomalies are described. The

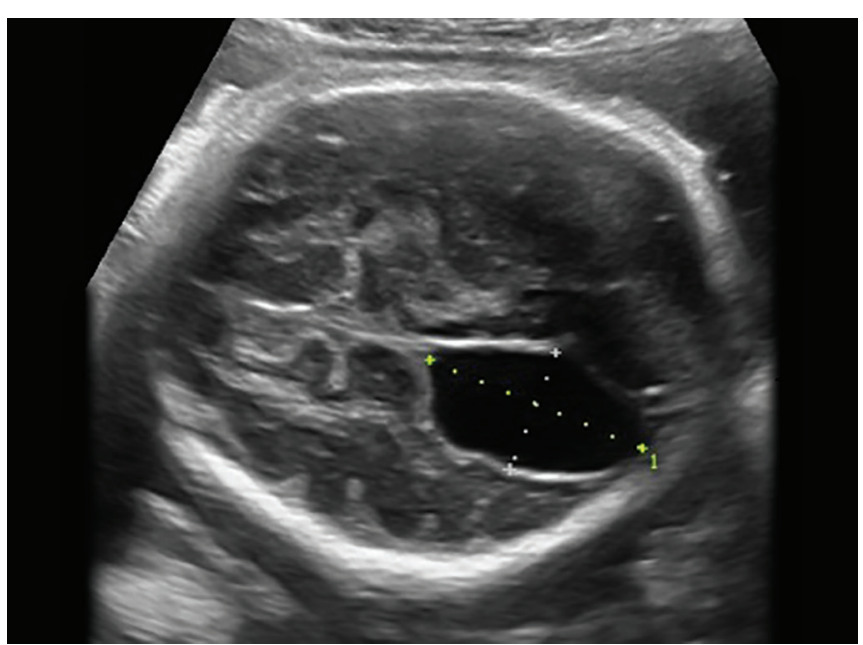

Fig. 4: Unilocular arachnoid cyst intracranial-associated anomalies are corpus callosum agenesis, absence of cavum septi pellucidum, cerebellar anomalies, Arnold-Chiari I malformation, cerebral sulcus disorders, and arteriovenous malformations. ${ }^{41,44}$ The extracranial-associated anomalies are sacrococcygeal tumors, tetralogy of Fallot, and type 1 neurofibromatosis. ${ }^{35,38,45,46}$ The risk of chromosomal abnormalities is very low. The recurrence risk does not seem to increase in the next pregnancy, except for autosomal recessive or X-linked inheritance pathology, such as Aicardi syndrome, in which intracranial anomalies are associated with the presence of interhemispheric cysts. ${ }^{41}$

The differential diagnosis is with porencephalic cysts, schizencephaly, Galen vein malformation, and cystic tumors.

The prognosis of a fetus with an arachnoid cyst mainly depends on the presence of associated malformations within or outside the CNS, or the progressive enlargement of the cysts. ${ }^{47-50}$ Yin et $\mathrm{al}^{51}$ showed a good prognosis in $80 \%$ of the cases in terms of behavior, neurological development, and intelligence. Arachnoid cysts are often asymptomatic; rare cases are described in which the presence of arachnoid cyst may induce epilepsy, motor or sensory impairments, or hydrocephalus. ${ }^{42}$

The prognosis seems good even in cases requiring surgical drainage.$^{52,53}$ The rate of surgery in symptomatic infants with isolated arachnoid cyst is about $34.7 \%{ }^{41}$ and includes shunting, open or endoscopic fenestrations, and stereotaxic aspiration. ${ }^{53-57}$

Prenatal counseling requires a good awareness of the outcome of arachnoid cysts. ${ }^{58}$ An accurate diagnosis has significant implications for adequate and reasonable prenatal counseling, especially regarding treatment options. An interdisciplinary approach involving obstetricians, pediatric neurologists, and neurosurgeons may avoid the high rate of pregnancy termination associated with this condition.

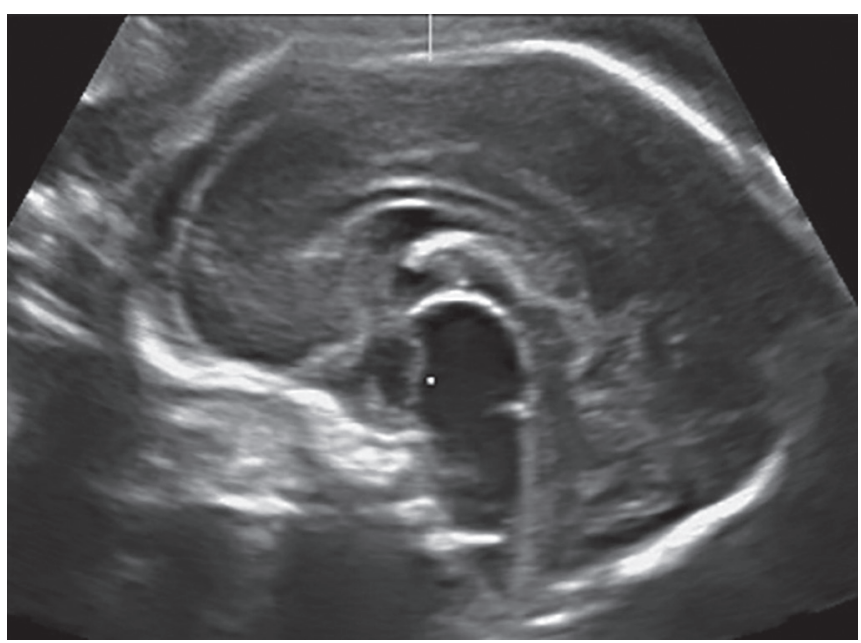

Fig. 5: Suprasellar arachnoid cyst 


\section{CAVUM VELI INTERPOSITI CYST}

The CVI is a space within the double-layered tela choroidea of the third ventricle. It is situated in the anteroinferior part of the splenium of the corpus callosum; the column of the fornix separates it from the cavum septi pellucidi and the cavum vergae. Occasionally, this space is fluidfilled and sonographically visible as an interhemispheric anechoic cyst, defined as CVI cyst. ${ }^{56}$ The internal cerebral veins run inferiorly. ${ }^{58}$ Embryologically, CVI is a real cistern that originates from diencephalus by an extension of the pia mater, which protrudes in the primitive neural tube in the third month of gestation. The pathogenetic mechanism could result from an increase in the size of the cisterna due to an anomaly separation of the crura of the fornix. ${ }^{22}$

On ultrasound, in the axial view, the cyst appears like an anechoic interhemispheric lesion situated posteriorly of the thalamus, while in the midsagittal scan, it is situated below the splenium of the corpus callosum (Fig. 6). The column of the fornix separates it from the cavum septi pellucidi and the cavum Vergae. The internal cerebral veins normally run posteriorly above the splenium of the corpus callosum to form the Galen vein later; in these cases, they are dislocated inferiorly and laterally by the cyst.

The differential diagnosis is with the expansion of the cavum septi pellucidi or cavum Vergae, with arachnoid cyst of the quadrigeminal cistern. The sagittal view is useful to distinguish the expansion of the cavum septi pellucidi or cavum vergae, which are present anteriorly and superiorly of the column of the fornix and below the anterior part of the corpus callosum. The arachnoid cyst of the quadrigeminal cistern is located below the internal cerebral veins and it can press the tectum of the mesencephalon.

Generally, the prognosis is good when isolated cysts are found. Few cases are described in literature with

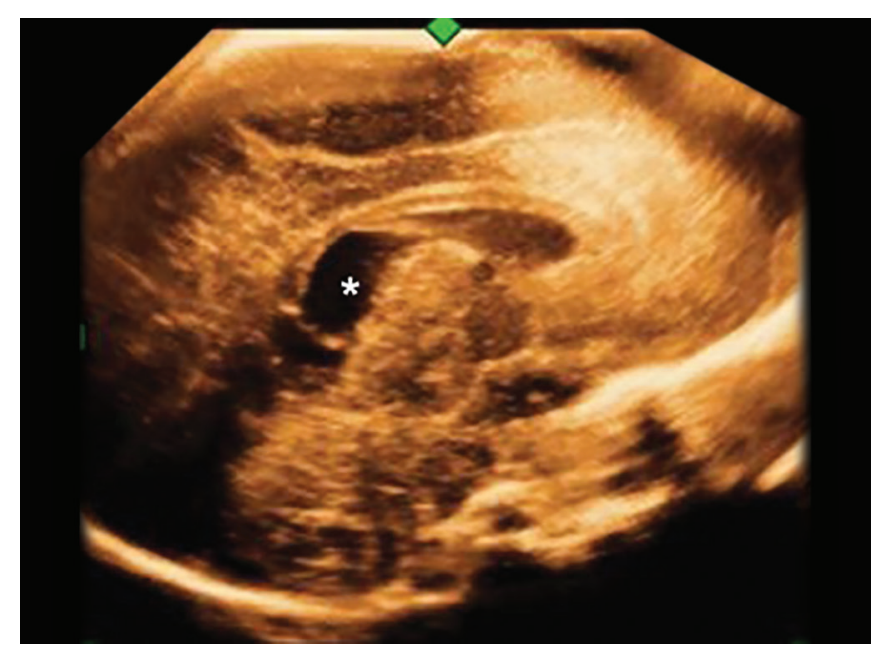

Fig. 6: Cavum veli interpositi cyst (*) located below the splenium of the corpus callosum intracranial-and extracranial-associated anomalies in about 31 and 6\% respectively. Ventriculomegaly is described in the $15 \%$ of the cases. ${ }^{59}$ The risk of chromosomal abnormalities is low and the need of postnatal surgery is linked to the dimension and symptom of patients. In some cases, psychotic disorders, motor or sensory impairments, hydrocephalus, and epilepsy are described. ${ }^{41,60-62}$

\section{REFERENCES}

1. Pappalardo EM, Militello M, Rapisarda G, Imbruglia L, Recupero S, Ermito S, Dinatale A, Carrara S, Cavaliere A. Fetal intracranial cysts: prenatal diagnosis and outcome. J Prenat Med 2009 Apr-Jun;3(2):28-30.

2. Choi JU, Kim DS. Pathogenesis of arachnoid cyst: congenital or traumatic? Pediatr Neurosurg 1998 Nov;29(5):260-266.

3. Pierre-Kahn A, Sonigo P. Malformative intracranial cysts: diagnosis and outcome. Childs Nerv Syst 2003 Aug;19(7-8):477-483.

4. Pilu G, Falco P, Perolo A, Sandri F, Cocchi G, Ancora G, Bovicelli L. Differential diagnosis and outcome of fetal intracranial hypoechoic lesions: report of 21 cases. Ultrasound Obstet Gynecol 1997 Apr;9(4):229-236.

5. Mei, CM.; Alvord, EC. Schizencephaly, porencephaly and hydranencephaly in pediatric neuropathology. Philadelphia (PA): Williams and Wilkins; 1995. pp. 185-195.

6. Paladini, D.; Volpe, P. Destructive lesions: porencephaly. In: Ultrasound of congenital fetal anomalies: differential diagnosis and prognostic indicators. 1st ed. London: Informa Healthcare; 2007. pp. 47-51.

7. Chen CP. Prenatal diagnosis of arachnoid cysts. Taiwan J Obstet Gynecol 2007 Sep;46(3):187-198.

8. Barjot $\mathrm{P}$, von Theobald $\mathrm{P}$, Refahi N, Delautre V, Herlicoviez M. Diagnosis of arachnoid cysts on prenatal ultrasound. Fetal Diagn Ther 1999 Sep-Oct;14(5):306-309.

9. Larroche JC. Sub-ependymal pseudo-cysts in the newborn. Biol Neonate 1972;21(3):170-183.

10. Shen EY, Huang FY. Subependymal cysts in normal neonates. Arch Dis Child 1985 Nov;60(11):1072-1074.

11. Heibel M, Heber R, Bechinger D, Kornhuber HH. Early diagnosis of perinatal cerebral lesions in apparently normal fullterm newborns by ultrasound of the brain. Neuroradiology 1993 Jan;35(2):85-91.

12. Rademaker KJ, De Vries LS, Barth PG. Subependymal pseudocysts: ultrasound diagnosis and findings at follow-up. Acta Paediatr 1993 Apr;82(4):394-399.

13. Stadlan EM, Sung JG. Congenital rubella encephalopathy. J Neuropathol Exp Neurol 1967 Jan;26(1):115.

14. Gilles F. Congenital rubella encephalopathy. J Neuropathol Exp Neurol 1967;26:115.

15. Bale JF Jr, Sato Y, Eisert D. Progressive postnatal subependymal necrosis in an infant with congenital cytomegalovirus infection. Paediatr Neurol 1986 Nov-Dec;2(6):367-370.

16. Soares de Souza A, Moraes Dias C, Braga FD, Terzian AC, Estofolete CF, Oliani AH, Oliveira GH, Brandão de Mattos CC, de Mattos LC, Nogueira ML, et al. Fetal infection by zika virus in the third trimester: report of 2 cases. Clin Infect Dis 2016 Dec;63(12):1622-1625.

17. Russel IM, van Sonderen L, van Straaten HL, Barth PG. Subependymal germinolytic cysts in Zellweger syndrome. Pediatr Radiol 1995 Jun;25(4):254-255.

18. Cohen HL, Sloves JH, Laungani S, Glass L, DeMarinis P. Neurosonographic findings in full-term infants born to 
maternal cocaine abusers: visualization of subependymal and periventricular cysts. J Clin Ultrasound 1994 Jun;22(5):327-333.

19. Smith LM, Qureshi N, Renslo R, Sinow RM. Prenatal cocaine exposure and cranial sonographic findings in preterm infants. J Clin Ultrasound 2001 Feb;29(2):72-77.

20. Makhoul IR, Zmora O, Tamir A, Shahar E, Sujov P. Congenital subependymal pseudocysts: own data and meta-analysis of the literature. Isr Med Assoc J 2001 Mar;3(3):178-183.

21. Rohrbach M, Chitayat D, Maegawa G, Shanske S, Davidzon G, Chong K, Clarke JT, Toi A, Tarnopolsky M, Robinson B, et al. Intracerebral periventricular pseudocysts in a fetus with mitochondrial depletion syndrome: an association or coincidence. Fetal Diagn Ther 2009 Mar;25(2):177-182.

22. Epelman M, Daneman A, Blaser SI, Ortiz-Neira C, Konen O, Jarrín J, Navarro OM. Differential diagnosis of intracranial cystic lesions at head US: correlation with CT and MR imaging. Radiographics 2006 Jan-Feb;26(1):173-196.

23. Esteban H, Blondiaux E, Audureau E, Sileo C, Moutard ML, Gelot A, Jouannic JM, Ducou le Pointe H, Garel C. Prenatal features of isolated subependymal pseudocysts associated with adverse pregnancy outcome. Ultrasound Obstet Gynecol 2015 Dec;46(6):678-687.

24. Malinger G, Lev D, Ben Sira L, Kidron D, Tamarkin M, Lerman-Sagie T. Congenital periventricular pseudocysts: prenatal sonographic appearance and clinical implications. Ultrasound Obstet Gynecol 2002 Nov;20(5):447-451.

25. Chitty LS, Chudleigh P, Wright E, Campbell S, Pembrey M. The significance of choroid plexus cysts in an unselected population: results of a multicenter study. Ultrasound Obstet Gynecol 1998 Dec;12(6):391-397.

26. Ghidini A, Strobelt N, Locatelli A, Mariani E, Piccoli MG, Vergani P. Isolated fetal choroid plexus cysts: role of ultrasonography in establishment of the risk of trisomy 18. Am J Obstet Gynecol 2000 Apr;182(4):972-977.

27. Walkinshaw SA. Fetal choroid plexus cysts: are we there yet? Prenat Diagn 2000 Aug;20(8):657-662.

28. Van den Hof MC, Wilson RD, Diagnostic Imaging Committee, Society of Obstetricians and Gynaecologists of Canada; Genetics Committee, Society of Obstetricians and Gynaecologists of Canada. Fetal soft markers in obstetric ultrasound. J Obstet Gynaecol Can 2005 Jun;27(6):592-636

29. Bronsteen R, Lee W, Vettraino IM, Huang R, Comstock CH. Second trimester sonography and trisomy 18: the significance of isolated choroid plexus cysts after an examination that includes the fetal hands. J Ultrasound Med 2004 Feb;23(2):241-245.

30. Odake G, Tenjin H, Murakami N. Cyst of the choroid plexus in the lateral ventricle: case report and review of the literature. Neurosurgery 1990 Sep;27(3):470-476.

31. Lam AH, Villanueva AC. Symptomatic third ventricular choroid plexus cysts. Pediatr Radiol 1992 Oct;22(6):413-416.

32. Parizek J, Jakubec J, Hobza V, Nemecková J, Cernoch Z, Sercl M, Zizka J, Spacek J, Nemecek S, Suba P. Choroid plexus cyst of the left lateral ventricle with intermittent blockage of the foramen of Monro, and initial invagination into the III ventricle in a child. Childs Nerv Syst 1998 Dec;14(12):700-708.

33. Peraud A, Illner A, Rutka JT. Intraventricular congenital lesions and colloid cysts. Neurosurg Clin N Am 2003 Nov;14(4):607-619.

34. Nahed BV, Darbar A, Doiron R, Saad A, Robson CD, Smith ER. Acute hydrocephalus secondary to obstruction of the foramen of Monro and cerebral aqueduct caused by a choroid plexus cyst in the lateral ventricle: case report. J Neurosurg 2007 Sep;107(3 Suppl):236-239.

35. Pascual-Castroviejo I, Roche MC, Martínez Bermejo A, Arcas J, García Blazquez M. Primary intracranial arachnoidal cysts. A study of 67 childhood cases. Childs Nerv Syst 1991 Sep;7(5):257-263.

36. Banna M. Arachnoid cysts on computed tomography. AJR Am J Roentgenol 1976 Dec;127(6):979-982.

37. Chuang S, Harwood-Nash D. Tumors and cysts. Neuroradiology 1986 Oct;28(5-6):463-475.

38. Menezes AH, Bell WE, Perret GE. Arachnoid cysts in children. Arch Neurol 1980 Mar;37(3):168-172.

39. Robinson RG. Congenital cysts of the brain: arachnoid malformations. Prog Neurol Surg 1971;4:133-174.

40. Blaicher W, Prayer D, Kuhle S, ,Deutinger J, Bernaschek G. Combined prenatal ultrasound and magnetic resonance imaging in two fetuses with suspected arachnoid cysts. Ultrasound Obstet Gynecol 2001 Aug;18(2):166-168.

41. Youssef A, D'Antonio F, Khalil A, Papageorghiou AT, Ciardulli A, Lanzone A, Rizzo G, Thilaganathan B, Pilu G. Outcome of fetuses with supratentorial extra-axial intracranial cysts: a systematic review. Fetal Diagn Ther 2016 Apr;40(1):1-12

42. Norton, ME.; Scoutt, LM.; Feldstein, VA. Callen's ultrasonography in obstetrics and gynecology. 6th ed. Philadelphia (PA): Elsevier; 2016.

43. Glenn OA, Barkovich J. Magnetic resonance imaging of the fetal brain and spine: an increasingly important tool in prenatal diagnosis: part 2. AJNR Am J Neuroradiol 2006 Oct;27(9):1807-1814.

44. Malinger G, Kidron D, Schreiber L, Ben-Sira L, Hoffmann C, Lev D, Lerman-Sagie T. Prenatal diagnosis of malformations of cortical development by dedicated neurosonography. Ultrasound Obstet Gynecol 2007 Feb;29(2):178-191.

45. Galassi E, Tognetti F, Frank F, Fagioli L, Nasi MT, Gaist G. Infratentorial arachnoid cysts. J Neurosurg 1985 Aug;63(2): 210-217.

46. Jones RF, Warnock TH, Nayanar V, Gupta JM. Suprasellar arachnoid cysts: management by cyst wall resection. Neurosurgery 1989 Oct;25(4):554-561.

47. Al-Holou WN, Yew AY, Boomsaad ZE, Garton HJ, Muraszko KM, Maher CO. Prevalence and natural history of arachnoid cysts in children. J Neurosurg Pediatr 2010 Jun;5(6): 578-585.

48. Fujimura J, Shima Y, Arai H, Ogawa R, Fukunaga Y. Management of a suprasellar arachnoid cyst identified using prenatal sonography. J Clin Ultrasound 2006 Feb;34(2):92-94.

49. Goksu E, Kazan S. Spontaneous shrinkage of a suprasellar arachnoid cyst diagnosed with prenatal sonography and fetal magnetic resonance imaging: case report and review of the literature. Turk Neurosurg 2015;25(4):670-673.

50. Gedikbasi A, Palabiyik F, Oztarhan A, Yildirim G, Eren C, Ozyurt SS, Ceylan Y. Prenatal diagnosis of a suprasellar arachnoid cyst with 2- and 3-dimensional sonography and fetal magnetic resonance imaging: difficulties in management and review of the literature. J Ultrasound Med 2010 Oct;29(10):1487-1493.

51. Yin L, Yang Z, Pan Q, Zhan J, Li X, Wang, Ye Y, Deng X, $\mathrm{Hu} C$. Sonographic diagnosis and prognosis of fetal arachnoid cysts. J Clin Ultrasound 2017 Oct.

52. Zada G, Krieger MD, McNatt SA, Bowen I, McComb JG. Pathogenesis and treatment of intracranial arachnoid cysts 
in pediatric patients younger than 2 years of age. Neurosurg Focus 2007;22(2):E1.

53. Pradilla G, Jallo G. Arachnoid cysts: case series and review of the literature. Neurosurg Focus 2007 Feb;22(2):E7.

54. Crimmins DW, Pierre-Kahn A, Sainte-Rose C, Zerah M. Treatment of suprasellar cysts and patient outcome. J Neurosurg 2006 Aug;105(2 Suppl):107-114.

55. Yang SH, Lee KS, Sung JH, Son BC, Jeun SS, Kang JK. Surgical decompression of supratentorial arachnoid cysts in pediatric patients younger than one year. Pediatr Neurosurg 2008 Nov;44(6):465-470.

56. D'Addario V, Pinto V, Rossi AC, Pintucci A, Di Cagno L. Cavum veli interpositi cyst: prenatal diagnosis and postnatal outcome. Ultrasound Obstet Gynecol 2009 Jul;34(1):52-54.

57. Marinov M, Undjian S, Wetzka P. An evaluation of the surgical treatment of intracranial arachnoid cysts in children. Childs Nerv Syst 1989 Jun;5(3):177-183.
58. Garel C, Moutard ML. Main congenital cerebral anomalies: how prenatal imaging aids counseling. Fetal Diagn Ther 2014 Feb;35(4):229-239.

59. Chen CY, Chen FH, Lee CC, Lee KW, Hsiao HS. Sonographic characteristics of the cavum velum interpositum. AJNR Am J Neuroradiol 1998 Oct;19(9):1631-1635.

60. Supprian T, Bengel D, Hofmann E, Fallgatter AJ, Franzek E. Cavum veli interpositi and psychotic disorder in a monocygotic twin. Eur Arch Psychiatry Clin Neurosci 2000 Apr;250(2): 76-78.

61. Raimondi AJ, Gutierrez FA, Jones RR, Winston SR. Cystic cavum veli interpositi associated with normal or low pressure hydrocephalus. Childs Brain 1975 Feb;1(5): 291-305.

62. Gangemi M, Donati P, Maiuri F, Sigona L. Cyst of the velum interpositum treated by endoscopic fenestration. Surg Neurol 1997 Feb;47(2):134-136, discussion 136-137. 